\title{
Influence of composition (Pd) In-, Co-containing aluminia- and zirconia-based catalysts on simultaneous reduction of nitrogen(I, II) oxides by $\mathrm{CO}$
}

\author{
T.M. Boichuk ${ }^{1,2}$, S.M. Orlyk ${ }^{1}$ \\ 1. L.V. Pisarzhevskii Institute of Physical Chemistry of the NAS of Ukraine, 31 Prospekt Nauky, Kyiv, Ukraine \\ 2. National University of Food Technologies, 68 Volodymyrska str., Kyiv, Ukraine \\ E-mail: boichuk_tm@ukr.net, orlyk@inphyschem-nas.kiev.ua
}

\begin{abstract}
It is shown that binary In-, Co-oxide supported catalysts show high activity in the reactions of simultaneous reduction of nitrogen(I, II) oxides by $\mathrm{CO}$, which depends on the nature support $\left(\mathrm{Al}_{2} \mathrm{O}_{3}\right.$, $\mathrm{ZrO}_{2}$ ), a sequence of the active components introduction. Structured Pd-containing In-, Co-oxide catalysts are characterized by high activity, moisture and sulfur resistance, low content of $P d(0.1)$ and can be used for complex purification of waste gases from nitrogen oxides and $\mathrm{CO}$.
\end{abstract}

Keywords - DeNOx, In-Co-oxide catalysts, $\mathrm{Al}_{2} \mathrm{O}_{3}, \mathrm{ZrO}_{2}, \mathrm{CO}, \mathrm{Pd}$, moisture resistance

\section{Introduction}

One of the most important challenges for scientific and applied researches is reduction of nitrogen oxides in gas emissions mobile and stationary sources, as evidenced by the introduction of morestrict norms for emissions into the environment (EURO-VI). One of the most efficient methods for neutralization of nitrogen(I, II) oxides in exhaust gases is catalytic reduction with various reducing agents $\left(\mathrm{CO}\right.$ and $\left.\mathrm{C}_{\mathrm{n}} \mathrm{H}_{\mathrm{m}}\right)$. The decrease of inhibiting effect of $\mathrm{SO}_{2}, \mathrm{O}_{2}$ and $\mathrm{H}_{2} \mathrm{O}$ to be the critical factor in the design of catalysts of elimination of nitrogen oxides from "tail" gases. Now the main attention is focused on structured catalysts in the form of monolithic blocks, in particular, because of the wide selection of options for constructive solutions, low gas-dynamic resistance, easy placement in reactor.

\section{Results}

This paper presents the results of study of the effect of composition of In-, Co-oxide catalysts of zirconium and aluminia base as well as doped $\mathrm{Pd}(0.1 \%)$, also formed on carriers with honeycomb monoliths ( $\mathrm{Pd}) \mathrm{In}_{2} \mathrm{O}_{3} / \mathrm{Co}_{3} \mathrm{O}_{4} / \mathrm{Al}_{2} \mathrm{O}_{3}\left(\mathrm{ZrO}_{2}\right) /$ kaolino-aerosil (KA) on their activity in the process of simultaneous reduction of $\mathrm{N}_{2} \mathrm{O}$ and $\mathrm{NO}$ with carbon monoxide. The influence of oxygen, water vapor and $\mathrm{SO}_{2}$ in the reaction mixture on the activity of catalysts were also studied.

It was shown that catalytic properties of composites with binary active phase differ significantly from the individual In-, Co-oxides deposited on $\mathrm{Al}_{2} \mathrm{O}_{3}$ and $\mathrm{ZrO}_{2}$. Binary catalysts exhibit higher activity in the investigated process, which depends on the sequence of active components introduction (cobalt and indium oxides), the nature of the catalyst carrier, acidic properties of the surface. The high catalytic activity of In-Co / $\mathrm{Al}_{2} \mathrm{O}_{3}$ takes place may be the positive effect of $\mathrm{In}_{2} \mathrm{O}_{3}$ on the stabilization of cobalt in the state of $\mathrm{Co}$ (II) in the composition of highly dispersed cobalt oxide clusters [1]. This catalyst also characterized by greater moisture resistance: $90-98 \%$ conversion of reagents is achieved at temperatures of $450-500{ }^{\circ} \mathrm{C}$ in reaction mixtures with $\mathrm{H}_{2} \mathrm{O}$ (fig. 1, tabl. 1).

In reaction mixtures containing excessive amounts of oxidizing agents $/ \mathrm{N}_{2} \mathrm{O}+\mathrm{NO}+\mathrm{CO}_{2}$ $+\mathrm{H}_{2} \mathrm{O}+\mathrm{O}_{2}$ /, along with $99 \%$ conversion of $\mathrm{NO}$ and $\mathrm{CO}$, low conversion of $\mathrm{N}_{2} \mathrm{O}(17-45 \%$ at 570

${ }^{\circ}$ C) can be explained with the competition of oxidant molecules $\mathrm{N}_{2} \mathrm{O}$, NO, and $\mathrm{O}_{2}\left(\mathrm{H}_{2} \mathrm{O}\right)$ for the active sites of the catalyst. Clusters of cobalt(II) oxide in the Co-In / $\mathrm{Al}_{2} \mathrm{O}_{3}$ and isolated $\mathrm{Co}^{2+}$ ions in In-, Co- HZSM-5 (FER) zeolite catalysts [2] are the active sites for NO oxidation by molecular oxygen to $\mathrm{NO}_{2}$ - the most reactive oxidant with respect to $\mathrm{CO}$ in the series: $\mathrm{NO}_{2}>\mathrm{O}_{2}>$ NO. This may explain the high activity of $5 \% \mathrm{In}_{2} \mathrm{O}_{3} / 5 \% \mathrm{Co}_{3} \mathrm{O}_{4} / \mathrm{Al}_{2} \mathrm{O}_{3}$ catalyst with respect to NO: at $310^{\circ} \mathrm{C}, 100 \%$ conversion of nitrogen monoxide and $\mathrm{CO}$ is achieved (tabl. 1).

The introduction of 0.1 mass $\%$ palladium into $\mathrm{In}-, \mathrm{Co}-, \mathrm{Zr}$ oxide composites significantly enhances their activity in the reduction of $\mathrm{N}_{2} \mathrm{O}$ and $\mathrm{NO}$ by carbon monoxide. 


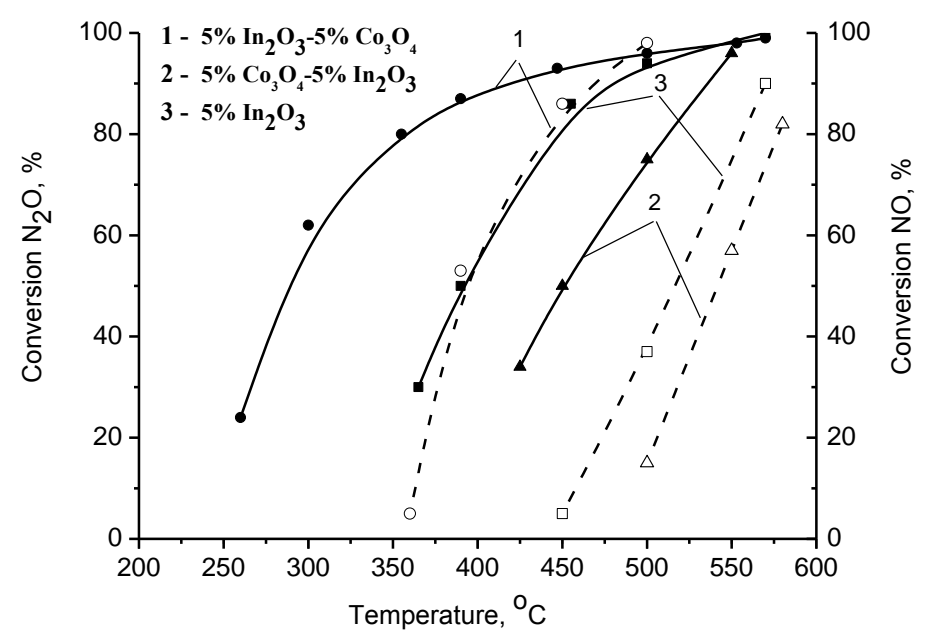

Fig.1. Temperature dependences of $\mathrm{N}_{2} \mathrm{O}$ (solid lines) and $\mathrm{NO}$ (dashed lines) conversion on the catalysts $\mathrm{In}_{2} \mathrm{O}_{3}, \mathrm{Co}_{3} \mathrm{O}_{4} / \mathrm{Al}_{2} \mathrm{O}_{3}$ for reaction mixtures: $0.5 \% \mathrm{~N}_{2} \mathrm{O}+0.2 \% \mathrm{NO}+1.5 \% \mathrm{CO}$ in $\mathrm{He}$.

Table 1

Simultaneous reduction of nitrogen(I, II) oxides by $\mathrm{CO}$ in the presence of oxidizing agents $\left(\mathrm{H}_{2} \mathrm{O}, \mathrm{O}_{2}\right) / 0.5 \% \mathrm{~N}_{2} \mathrm{O}+0.2 \% \mathrm{NO}+1.5 \% \mathrm{CO}+2 \% \mathrm{H}_{2} \mathrm{O}\left(5 \% \mathrm{O}_{2}\right)$ in $\mathrm{He} ; \mathrm{W}=6000 \mathrm{~h}^{-1} /$

\begin{tabular}{|c|r|c|c|}
\hline \multirow{2}{*}{$\begin{array}{c}\text { Catalysts } \\
\left(\text { Specific surface area, }{ }^{2} / \mathrm{g}\right)\end{array}$} & \multicolumn{3}{|c|}{ Conversion of $\mathrm{N}_{2} \mathrm{O}[\mathrm{NO}], \% / \mathrm{T},{ }^{\circ} \mathrm{C}$ for reaction mixtures: } \\
\cline { 2 - 4 } & $\mathrm{N}_{2} \mathrm{O}+\mathrm{NO}+\mathrm{CO}$ & $\begin{array}{c}\mathrm{N}_{2} \mathrm{O}+\mathrm{NO}+\mathrm{CO} \\
+\mathrm{H}_{2} \mathrm{O}\end{array}$ & $\begin{array}{c}\mathrm{N}_{2} \mathrm{O}+\mathrm{NO}+\mathrm{CO} \\
+\mathrm{H}_{2} \mathrm{O}+\mathrm{O}_{2}\end{array}$ \\
\hline $5 \% \mathrm{In}_{2} \mathrm{O}_{3} / \mathrm{Al}_{2} \mathrm{O}_{3}(80)$ & $90 / 480[83 / 570]$ & $93 / 560[61 / 580]$ & $17 / 570[99 / 450]$ \\
\hline $5 \% \mathrm{In}_{2} \mathrm{O}_{3} / \mathrm{ZrO}_{2}(67)$ & $55 / 550[52 / 550]$ & $55 / 550[52 / 550]$ & - \\
\hline $5 \% \mathrm{In}_{2} \mathrm{O}_{3} / 5 \% \mathrm{Co}_{3} \mathrm{O}_{4} / \mathrm{Al}_{2} \mathrm{O}_{3}(74)$ & $90 / 450[98 / 500]$ & $90 / 500[91 / 500]$ & $23 / 570[99 / 310]$ \\
\hline $2.5 \% \mathrm{In}_{2} \mathrm{O}_{3} / 10 \% \mathrm{Co}_{3} \mathrm{O}_{4} /$ & $90 / 580[90 / 570]$ & $90 / 570[90 / 570]$ & $45 / 580[99 / 380]$ \\
\hline $80 \% \mathrm{ZrO}_{2}+20 \% \mathrm{Al}_{2} \mathrm{O}_{3}(140)$ & & & \\
\hline $0.1 \% \mathrm{Pd} / 5 \% \mathrm{In}_{2} \mathrm{O}_{3} / 7 \% \mathrm{Co}_{\mathrm{x}} \mathrm{O}_{\mathrm{y}} / 9 \% \mathrm{ZrO}_{2} / \mathrm{KA}$ & $90 / 450[99 / 450]$ & $90 / 450[99 / 450]$ & $86 / 500[90 / 500]^{1}$ \\
\hline
\end{tabular}

/ for reaction mixtures: $0.5 \% \mathrm{~N}_{2} \mathrm{O}+0.2 \% \mathrm{NO}+1.5 \% \mathrm{CO}+2 \% \mathrm{H}_{2} \mathrm{O}+0.01 \% \mathrm{SO}_{2}$.

\section{Conclusion}

Developed granular and structured catalysts of $0.1 \% \mathrm{Pd} / 2.5-5 \% \mathrm{In}_{2} \mathrm{O}_{3} / 5 \% \mathrm{Co}_{3} \mathrm{O}_{4} /$ $\mathrm{ZrO}_{2} /(\mathrm{KA})$ showed high activity in the reaction of $\mathrm{N}_{2} \mathrm{O}+\mathrm{NO}+\mathrm{CO}$ (90-99\% conversion of $\mathrm{N}_{2} \mathrm{O}$ and $\mathrm{NO}$ is achieved by temperature $450{ }^{\circ} \mathrm{C}$ ), tolerance to the influence of moisture and sulfur compounds.

\section{References}

[1] X. Zhang, Q. Shen, C.He, C. Ma, Z. Liu, Z. Hao, "Promotional effects and mechanism of second cations on activity and stability of Co-MOR for nitrous oxide decomposition: UVVis spectroscopy and EXAFS analysis,“ Chem. Engineer. J., vol. 226, Jun., pp. 95-104, 2013.

[2] A. Kubacka, J. Janas, B. Sulikowski, "In/Co-ferrierite: A highly active catalyst for the $\mathrm{CH}_{4}$-SCR NO process under presence of steam," Appl Catal.B., vol. 69, no 1-2, Des., pp. 43-48, 2006. 